\title{
Relationship between race sentiment and regulatory focus and participation in training where elite shooters are late for a match
}

\author{
Sang-Hyuk Park ${ }^{1}$, Chang-Hoon Seong ${ }^{2}$, \& In-Hye Park ${ }^{3 *}$ \\ ${ }^{1}$ Korea Institute of Sport Science, ${ }^{2}$ Incheon University, $\&{ }^{3}$ KwangWoon University
}

\begin{abstract}
[Purpose] The purpose of this study was to find out the relationship between emotion and control focus and training involvement in games where elite shooters are late. [Methods] Thus, 228 elite shooters were selected and the research results were derived based on data analysis using discriminatory emotions, control focus, and training attendance scales. [Results] According to the analysis of the correlation between emotion, control focus, and training involvement, positive emotions of surprise, enjoyment, and interest showed a static relationship with improvement focus and training involvement, while negative emotions such as anger and guilt had a static relationship with prevention focus, but showed an inadequate relationship with training involvement. The multiple regression analysis between emotion and control focus showed that the improvement focus showed the most significant effect of enjoyment emotion, while the prevention focus showed that instability had the most effect on the prevention focus. Overall, the focus of improvement has been shown to be affected by training. Finally, it was found that positive sentiment had a positive effect on improvement focus and training involvement, while negative sentiment affected prevention focus and reduced cognitive involvement. [Conclusions] Positive sentiment toward the competition has been confirmed to enhance training participation by strengthening the focus of improvement, but negative sentiment has been shown to enhance the focus of prevention, reducing cognitive involvement.
\end{abstract}

Key Words: promotion focus, prevention focus, interest, surprise, emotions

\begin{abstract}
서 론
정서(emotion)는 모든 사람들이 공유하는 심리 기제 이며, 우리의 모든 일상생활 및 인간관계의 근간이 되는 중요한 심리적 요인이다. 일상생활에서 사람들은 정서를 유발하는 다양한 상황에 노출되고, 정서경험에 따라 정서 반응도 다양하게 나타난다. 정서는 20세기 초까지만 해 도 그 개념적 정의가 분명치 않아 정동 (affect)이나 느낌 (feeling)등과 혼용하여 사용되어 왔지만, 정서 연구자들 의 공통적 의견은 정서가 어떤 대상이나 상황을 지각하
\end{abstract}

논문 투고일 : 2020. 08. 31.

논문 수정일 : 2020. 10. 19.

게재 확정일 : 2020. 11. 25.

* 교신저자 : 박인혜(katie9910@ naver.com).
고, 그에 따르는 생리적 변화를 수반하는 복잡한 기제로 써 여러 가지 감정들을 포함하는 통합적인 개념으로 설명 하고 있다(Kim 1995; Kim, Kim, 2007; Byun \& Jo, 2011).

이는 정서가 비합리적이고 본능적 현상이며(Cole, Michel, \& Teti, 1994), 내적이고 측정하기 어려워 구체 적이고 명확한 측정이 어렵다는 관점을 포함하고 있다 (Kalat \& Shiota, 2007). 그러나 최근 들어 Darwin(Charles Robert Darwin)이 주장한 정서의 기 능적 효과성에 대한 관점을 기반으로 정서가 개인이 경험 하는 상황에 어떻게 적응하고, 어떤 기능을 하는지 규명 하는 연구가 발표되고 있다(Cole et al., 1994; Greenberg, 2001; Lee \& Joung, 2012, quotation). 정서의 기능적 효과성은 긍정 혹은 부정의 양분적인 
특성으로 정서의 기능을 설명한다. 긍정적 정서는 위험한 상황에 따른 대처에 도움을 주고, 자신과 타인의 욕구를 인식하고 해결하는데 도움을 준다. 특히 정서를 적절히 표현하고, 수용하는 것은 신체적-심리적 건강에 도움을 줄 뿐만 아니라(Goleman, 1995; Salovey \& Mayer, 1990), 대인관계에도 긍정적인 영향을 미친다(Kim \& Lee, 2014).

그러나 부정적 정서로 인한 효과는 무의식적으로 감정 을 억압하거나 의식적으로 억제하거나 회피하려고 애쓰 며, 이로 인해 억제된 감정들은 신체적 질병이나 대인관 계 등에서 여러 가지 문제를 일으킨다(Sloan, 2004, Yoon \& Jung, 2009; Choi \& Lee, Jang, 2011; Kim, Lee, 2014).

따라서 이러한 전제들은 긍정과 부정으로 정의되는 정 서의 조절이 얼마나 중요한지 잘 설명해주고 있다. 이러 한 정서의 관점을 효과적으로 설명하는 차별적 정서이론 (Differential Emotions Theory)은 정서에 대한 생물사 회적 이론의 하나로써 진화와 적응에 있어 필수적인 생물 학적, 사회적 기능을 지니고 있는 정서를 기본 정서로 정 의하며, 정서의 기능적 효과성을 잘 아우르는 이론이다. 차별적 정서 이론은 즐거움, 슬픔, 공포, 화 등과 같은 기 본 정서는 본질적으로 서로 다른 신경생물학적 과정을 포 함(Izard, 1971, 1977)한다고 전제한다(Lee, Kim \& Yoo, 2012). '정서'는 '기분'에 비해 자극의 원인이 명확하 지만 일시적으로 강하고, 일관성이 높고, 드물게 발생하 며, 행복, 자부심, 분노 등과 같이 상당히 구체적이다.

반면에 '기분'은 자극원인이 명확하지 않기 때문에 좋 다. 싫다 또는 접근.회피와 같이 이분법적 반응을 보이 고, 강도가 약하며, 일관성이 낮고 항상 존재하여 영향력 을 발휘 (Moon, et. al., 2009)한다고 본다. 따라서 정서 는 개인에게 동기를 부여하는 힘을 가지고 있고, 내적 감 각과 외적 표현을 포함하고 있는 복잡한 인식의 상태라고 정의할 수 있으며(Kim, 1994), 정서에 관한 일부 연구에 서는 정서경험을 긍정적 정서와 부정적 정서 차원으로 나누고, 이러한 정서 유형이 동기와 행동에 미치는 영향 을 검증하고 있다(Han, 2007; Byun \& Jo, 2011).

이러한 선행연구의 내용들은 스포츠 상황에서 효과적으로 설명될 수 있다. Ekkkekakis, Hartman과 Ladwig, (2020)은 운동수행과 강도에 따른 정서의 인식이 수행에 영향을 미 친다고 설명한다. 특히 생리적인 지표와 정서간의 관계를 알아보는 연구를 통해 운동 수준과 강도에 따라 정서의
변화가 역동적으로 일어난다고 설명하였다. 또한 Gondola와 Tuckman(1982)은 운동선수가 경기 수행 중 또는 후에 긍정적 정서변화를 겪게 되는데, 이런 긍정적 정서변화는 선수의 신체적, 정신적 안정감을 유발 한다고 보고하였다.

Gustafsson과 Skoog(2012)에 의하면 시합에 따른 긍 정적 정서 경험이 운동선수로서의 강한 정체성과 자존감 을 형성시켜 경기력을 향상 시킨다고 설명하였으며, Jones 등(2009)은 스트레스가 많은 시합 상황을 긍정적 으로 인식할수록 긍정적 정서를 경험하며, 시합을 위협적 으로 평가하는 선수는 높은 부정적 정서 상태를 경험한다 고 보고하였다(Lee, 2014).

이에 Lazarus(2000)는 정서의 인식이 선수들이 수행 하는 시합 결과를 예측할 수 있다고 제언하였으며, 시합 의 결과로부터 초래되는 평가와 후속 행 동에도 영향을 미 칠 것이라는 의견을 피력 하였다. 이렇듯 선수들은 경기 와 관련된 정서들을 어떻게 느끼느냐에 따라 경기력은 달 라 질 수 있으며, 시합이 부담스러운 상황과 어려운 경기 상황이라고 하더라도 긍정적 정서로 느낄 수 있도록 다양 한 방법을 찾아가는 것이 중요하다. 또한 이러한 방법은 성공적인 시합을 위한 훈련행동에도 영향을 미치기에 긍 정적인 정서를 유지하고 조절하는 것은 매우 중요하다 (Park, et.al., 2003). 따라서 선수들이 지각하는 시합에 대한 정서의 변화는 성공적인 결과를 이끌어내기 위해 목 표를 재설정하거나, 자기조절의 전략을 바꾸는 등 수행 동기에 영향을 주게 된다(Moon, et. al, 2009).

이처럼 동일한 사건이라도 정서를 어떻게 지각 하는 지에 따라 조절 지향성이 달라지며, 이를 통해 파생되는 행 동의 유형과 강도가 달라질 수 있음을 예측할 수 있다. 즉 개인이 처한 상황으로부터 정서를 평가할 때 정서가 자기 조절에 영향을 미칠 수 있음을 예상해 볼 수 있다 (Kim, 2011).

여기서 자기조절(Self-regulation)은 자신이 추구하 는 목표를 성취하기 위하여 동기, 인지, 행동, 정서를 조 절하고 유지해 나가는 역동적인 과정으로 정의된다 (Pintrich, 2004). 시합에 대한 자기조절의 과정은 자신에 대한 인식과 인지적 평가에 기인된다(Lazarus, 2000).

이는 선수가 경기 중에 자신의 신체적 상태, 심리적 상 태 등에 따라서 선수가 지각을 하고, 상대방이 나보다 강 해 보이는지 약해 보이는지, 또는 시합 상황에 영향을 받 아 시합에 대한 총체적 자기 평가를 하게 된다. 따라서 시 
합에 대한 인식에 따라 유기적인 동기적 행동을 조절할 것이라는 가설이 가능하다(Park, 2012). 그러므로 정서 를 긍정적 혹은 부정적으로 평가하고, 이러한 평가가 목 표로 설정된 목표 행동에 영향을 미치게 된다면, 이러한 정서와 동기의 관계는 초기 Higgins(1997)가 제안한 조 절초점 이론을 통해 효과적으로 설명될 수 있다.

조절초점은 질적으로 구분되는 두 가지 동기 지향성으 로 향상과 예방초점을 제시한다. 향상초점은 자기 성장을 고취하고 격려하며, 자기발달의 관점에서 과제 수행에 따 른 성공이나 이익을 지향하는 요인이며, 예방초점은 과제 수행과 관련된 위험한 요인으로부터 자기를 보호하고, 안 전하고자 하는 손실의 방어를 지향하는 요인이다.

조절초점과 동기 행동과의 관계를 검증한 Seong과 $\operatorname{Park}(2016)$ 은 운동선수들은 시합상황에서의 최적 수행 을 위해 자신의 동기를 유지하거나 조절하고, 변화시키는 데 이러한 과정 속에서 자기를 조절하려는 행동을 한다고 하였다. 그러므로 시합을 앞둔 상황에서 지각하는 정서와 조절초점을 통해 동기를 예측 할 수 있다고 설명하였다.

이러한 맥락에서 학습관여(academic engagement)는 정서와 조절초점을 통한 후속 행동을 예측하는데 유용하 게 설명할 수 있는 근거를 제공한다. 학습관여는 개인이 과제활동에 참여하는 수준을 알아보는 것으로 과제활동 을 시작하고 수행 할 때 보이는 인지적, 행동적 적극적인 행동의 특성으로 정의된다(Frediricks, Blumenfeld, \& Paris, 2004). 특히 학습관여는 학업성취나 학습 성과를 예측하는 선행변인으로 혹은 학습동기에 의한 결과를 설 명하는 준거 변인으로 크게 주목을 받고 있다(Skinner, Wellborn, \& Connell, 1990, Skinner \& Belmont, 1993; You, Song, 2013; Lee, Jang, 2013, Seong, et, al., 2015).

전술한 대로 관여(engagement)는 일반적으로 특정 상황이나 환경에 따라 개인이 가지는 관심이나 중요성, 목표 등을 나타내는 개념으로 개인의 실질적 행동을 예측 하는 특성을 가지고 있다. 이러한 관여를 Skinner 등 (1990)은 학교상황을 대입하여 학생들의 학교 및 수업 참여 (school engagement)의 개념으로 발전시켰으며, 학 습자의 학교에 대한 몰입 수준과 지식을 습득함에 있어 투자하는 심리적 노력과 학교생활에 대한 흥미로 설명된 다고 하였다(Yoon, 2016).

이와 같은 학습관여 개념은 기술과 전술 및 체력을 습 득하는 훈련 상황에도 동일하게 적용할 수 있다. 즉 학습
자로서 운동선수들 역시 훈련 상황에서 다양한 인지적 노 력을 하며, 흥미나 재미를 경험하고 행동적으로 과제를 수행함은 물론 자율적이고 주도적인 참여 특성을 보인다. 비록 두 상황에서 수행하는 과제의 특성은 다르지만 과제 를 학습하고 성취하는 상황이라는 점에서 참가자의 관여 개념은 동질적으로 정의될 수 있고 동일한 측정 구조로 설명될 수 있을 것이다. 나아가 학습관여 관련 연구들에 서 확인된 바와 같이 훈련 상황에서도 관여정도가 높은 선수들은 운동에 보다 동기적 성향을 보이며, 기술 습득 을 위한 훈련전략을 더욱 잘 활용하며 노력 및 수행의 지 속성이 높고, 훈련과정에 몰입은 물론 능동적 참여도가 높을 것으로 예상할 수 있다(Seong \& Jang, 2020). 그 러므로 이러한 정서 $\rightarrow$ 조절초점 $\rightarrow$ 훈련관여의 경로분석 을 통해 성공적인 시합 결과를 이끌어내는데 도움을 줄 수 있을 것으로 기대한다.

따라서 본 연구에서는 정서와 조절초점 및 훈련관여의 흐름을 알아보기 위하여 시합에 대한 예측이 가장 불가능 한 종목 중 하나인 사격종목을 선택하여 알아보았다. 사격 종목은 고도의 집중력을 기반으로 수행되는 경기이며, 안 정적인 격발 타이밍과 견고한 심리적 안정화가 경기에 영 향을 미치는 기록 종목이다. 특히 고도의 집중력과 정서적 안정성이 필요한 종목으로 선수들은 작은 정서적 변화에 도 민감하게 반응하고 수행에 직접적인 영향을 미치게 된 다. 또한 Ralf Brand, Panteleimon Ekkekakis(2017) 의 연구에서 제시된 정서-반응 이론(AffectiveReflective Theory: ART)에 근거할 때 사격 경기에서 성 공적인 결과를 이끌어내는데 중요한 요인은 시합에 대한 선수의 정서 인식과 평가이며, 정서는 어떻 게 인식하는지 에 따라 수행에 영향을 미친다고 설명한다. 특히 시합 상 황에서 나타나는 부정적이고 급격한 정서의 변화는 신체 적 밸런스의 붕괴 및 집중력의 저하를 일으키는 요인으로 나타나기도 하며, 심각한 경기력 저하를 야기하는 과정을 거치게 된다. 정서적 변화에 대응하기 위하여 격발 점수 와 정서적 변화를 교차적으로 비교하고, 격발 시 경험하 는 정서의 유형과 이에 대한 인지적 조절 전략의 방법을 강구함으로써 향후 사격선수들의 훈련관여에 미치는 영 향력을 알아볼 수 있다. 그러나 현재까지 선수들의 정서 를 인식하고 조절하며 동기적인 행동에 대한 영향력을 최 소화하는 심리적 안정화 전략은 선수 개개인의 능력과 성 향에 따라 큰 편차를 보이고 있다.

또한 인지와 정서, 동기 통합 모델(cognitive- 
motivational-relational theory of emotion: CMRT)에 근거하여 시합 상황에서의 정서 및 동기의 변화를 관측함 으로써 긍정적인 시합 결과를 예측할 수 있을 것으로 기 대된다.

따라서 CMRT이론에 근거할 때 시합에 대한 도전이나 위협의 지각이 긍정정서 및 부정정서를 야기함으로써 수 행에 영향을 미친다는 Nicholls et al(2012)의 주장에 따라 본 연구는 엘리트 및 국가대표 사격 선수들이 시합 상황에서 보여주는 정서적 변화와 동기 및 훈련행동의 인 과적 과정을 분석하고, 시합 상황에서 사격 선수들의 안 정적인 심리 유지와 훈련 행동의 강화를 위한 정보를 제 공하는데 목적이 있다.

\section{연구방법}

\section{연구 대상}

본 연구에 참여한 연구 대상자는 대한사격연맹 소속 엘리트 사격 선수를 대상으로 선정하였다. 먼저 정서와 조절초점 및 훈련관여의 관계를 알아보기 위하여 228 명 이 사격선수가 설문에 참여하였다. 이러한 과정에서 연구 대상들은 각 무선 표집(random sampling) 방법을 활용 하여 표집하였다. 대상자 특성은 〈Table 1)과 같다.

Table 1. Characteristic of the subjects

\begin{tabular}{cccccc}
\hline \hline \multirow{2}{*}{ Variables } & \multicolumn{4}{c}{ Career } & \\
\cline { 2 - 5 } & $\begin{array}{c}\text { less than } 5 \\
\text { years }\end{array}$ & $\begin{array}{c}\text { less than } 5 \\
\text { to 10 years }\end{array}$ & $\begin{array}{c}\text { more than } \\
10 \text { years }\end{array}$ & Total \\
\hline \multirow{2}{*}{$\begin{array}{c}\text { Gen } \\
\text { der }\end{array}$} & Male & 38 & 72 & 37 & 147 \\
\cline { 2 - 5 } & Female & 35 & 40 & 6 & 81 \\
\hline \multicolumn{2}{c}{ Total } & 73 & 112 & 43 & 228 \\
\hline \hline
\end{tabular}

〈Table 1〉에 제시된 바와 같이 남자는 147 명, 여자는 81 명이었으며, 5 년 미만의 경력은 73 명, 5 년에서 10 년 은 112 명, 10 년 이상의 경력은 43 명으로 총 228 명이 연 구에 참여하였다.

\section{연구 절차}

본 연구의 절차는 먼저 전국 사격 대회를 직접 방문하
여 연구 대상자들과의 개별적 면담을 통해 연구의 취지를 설명하고, 협조를 타진한 대상자들을 설문조사 하였다.

사격 경기의 특성상 2 시간 정도 여유를 두고 시합장에 도착한 선수들을 대상으로 하였으며, 일반적으로 시합 전 30 분에서 1 시간 이내에 측정을 진행하였다. 또한 이해부 족으로 인한 오류를 최소화하고 연구 주제에 대해 충분히 이해할 수 있게 질문에 성실히 답변하도록 보조 연구자를 2 명 배치하여 사전에 교육하였으며, 자유로운 설문환경 을 조성하도록 노력하였다.

또한 국가생명윤리심의위원회(National Bioethics Committee)의 연구지침을 토대로 개인정보 보호를 위해 설문지에는 성별과 소속, 경력을 제외한 다른 기입 사항 은 표시하지 않았으며, 인터뷰나 면접과정에서 습득되는 연구 참여자의 개인정보는 습득 후 바로 폐기 처분한다고 이를 안내 하였다. 이러한 절차를 거쳐 확보된 설문지와 내용은 자료분석 절차에 기준하여 결과를 산출하였다.

\section{측정도구 및 방법}

\section{차별적 정서 척도의 타당도 및 신뢰도 검증 결과}

엘리트 사격 선수들이 시합 시 경험하는 정서를 알아 보기 위하여 차별적 정서척도(DES-IV; Izard, Libero, Putnam, \& Haynes, 1993)를 한국판으로 타당화한 Lee \& Kim, Yoo(2012)의 연구에서 제시된 척도를 사용 하였다.

차별적 정서 척도는 인간의 12 가지 기본 정서를 측정하 는 자기보고식 척도로써 각 정서에 해당되는 3 문항씩 총 36문항으로 구성되어 있다. 차별적 정서는 상황에 따라 지각되는 정서를 측정하는 것으로써 특정 상황을 지정하 거나, 경험하는 상황에서 문항에 응답하도록 되어 있다.

차별적 정서척도는 5 점 리커트 반응 방식을 활용하여 '전혀 아니다'의 1점부터 '매우 그렇다'의 5점까지 반응하도 록 구성 되어있다. 차별적 정서척도가 측정하는 12 가지 기 본 정서는 흥미(interest), 즐거움(enjoyment), 놀람 (surprise), 슬픔(sadness), 분노(anger), 혐오 (disgust), 경멸(contempt), 공포(fear), 죄책감(guilt), 수치심(shame), 수줍음(shyness), 내부적대감(hostility inward)으로 구성되어 있다.

Izard 등(1993)은 12 가지 정서 요인 중 흥미, 즐거움, 놀람 요인은 긍정 정서로 분류하였으며, 나머지 정서 요 인들은 부정정서로 분류한 바 있다. 따라서 본 연구에서 
사용된 차별적 정서 척도에 대한 타당도 검증을 위하여 탐색적 요인분석을 실시하여 구인타당도를 검증하였으 며, 신뢰도 검증을 실시하여 문항 간 내적 일치도를 통해 신뢰도 검증을 실시하였다. 탐색적 요인분석 결과는 아래 〈Table 2〉와 같다.

〈Table 2〉에 나타난 결과와 같이 사격 선수들이 경험

Table 2. Exploratory factor analysis of DES-IV

\begin{tabular}{|c|c|c|c|c|c|c|c|}
\hline \multirow[b]{2}{*}{$\begin{array}{l}\text { questionnaire } \\
\text { item }\end{array}$} & \multicolumn{7}{|c|}{ Name of factor \& Factor loadings } \\
\hline & Anxiety & surprise & disgust & anger & $\begin{array}{l}\text { enjoy } \\
\text { ment }\end{array}$ & guilt & $\begin{array}{c}\text { interest } \\
.\end{array}$ \\
\hline Q30 & .855 & -.029 & .071 & -.086 & .007 & .011 & .003 \\
\hline Q32 & .851 & .014 & -.109 & .024 & -.138 & .071 & -.010 \\
\hline Q29 & .830 & -.060 & -.034 & -.097 & .044 & -.020 & .031 \\
\hline Q31 & .826 & -.001 & .094 & .061 & -.027 & -.073 & -.068 \\
\hline Q36 & .554 & .099 & -.329 & .096 & .103 & -.084 & -.093 \\
\hline Q8 & -.026 & .991 & .009 & -.008 & -.068 & -.004 & -.048 \\
\hline Q7 & -.016 & .824 & -.013 & .039 & .010 & -.024 & .075 \\
\hline Q9 & .016 & .784 & .056 & -.078 & -.018 & .017 & .009 \\
\hline Q6 & .050 & .479 & -.039 & .065 & .212 & .058 & .206 \\
\hline Q18 & -.050 & .017 & -.894 & -.019 & -.043 & -.023 & -.027 \\
\hline Q17 & -.050 & .090 & -.824 & -.087 & -.065 & -.035 & -.098 \\
\hline Q16 & -.067 & .066 & -.792 & -.057 & -.097 & -.056 & -.073 \\
\hline Q13 & .102 & .095 & .011 & -.760 & .125 & -.053 & -.102 \\
\hline Q14 & .189 & .073 & -.178 & -.512 & .152 & -.037 & -.051 \\
\hline Q15 & .017 & -.008 & -.332 & -.507 & .049 & -.063 & -.163 \\
\hline Q4 & -.140 & .076 & .025 & .028 & .616 & -.070 & .423 \\
\hline Q5 & -.055 & .152 & .045 & .124 & .587 & -.052 & .332 \\
\hline Q25 & -.011 & .054 & -.011 & .006 & .042 & -.913 & -.061 \\
\hline Q26 & .058 & -.058 & .059 & -.015 & .085 & -.884 & -.062 \\
\hline Q24 & .098 & -.006 & -.063 & -.078 & -.239 & -.584 & .120 \\
\hline Q27 & .192 & -.074 & -.133 & -.097 & .148 & -.569 & -.085 \\
\hline Q2 & .025 & .074 & -.041 & -.012 & .006 & .089 & .736 \\
\hline Q3 & -.020 & .105 & .000 & -.033 & .124 & .022 & .722 \\
\hline Q1 & -.109 & .033 & .107 & .061 & .013 & -.026 & .656 \\
\hline eigen value & 14.031 & 4.513 & 3.049 & 1.647 & 1.443 & 1.166 & 1.092 \\
\hline$\%$ of variable & 14.031 & 12.537 & 8.468 & 4.574 & 4.008 & 3.240 & 3.033 \\
\hline $\begin{array}{l}\text { cumulative } \\
\text { variable }\end{array}$ & 38.97 & 51.51 & 59.98 & 64.55 & 68.56 & 71.80 & 74.83 \\
\hline $\begin{array}{c}\text { Cronbach's } \\
\text { alpha }\end{array}$ & .781 & .884 & .794 & .771 & .822 & .755 & .699 \\
\hline \multicolumn{6}{|c|}{ Kaiser-Meyer-Olkin(KMO) } & \multicolumn{2}{|c|}{.912} \\
\hline \multicolumn{6}{|c|}{ Bartlett's test } & \multicolumn{2}{|c|}{$7104.401^{* * *}$} \\
\hline
\end{tabular}

하는 정서는 불안, 놀람, 혐오, 분노, 즐거움, 죄책감, 흥 미의 7 개 요인 24 문항으로 나타났다. 기타 다른 문항과 요인은 동일한 요인에 중복 포함되어 있었거나, 요인 부 하량의 미달(.3이하), 잠재변수를 설명하는데 타당하지 않은 문항, 신뢰도를 떨어뜨리는 문항 등으로 확인되어 단계적으로 삭제되었다.

구체적으로 도출된 잠재변수의 다중상관을 검증하기 위한 Bartlett의 단위행렬검정(Bartlett's test of sphericity)결과 $p<.05$ 의 유의한 통계적 유의수준을 보 여줌으로써 잠재변수의 다중상관은 검증되었으며, Kiser-Meyer-Olkin의 표준적합도(MSA: measure of sampling adequency) 수치는 .912로 나타났다.

또한 이들 7 개 요인의 총 설명변량은 $74 \%$ 를 설명하고 있으며, 도출된 각 요인의 요인 부하량은 .47 .99를 나 타내었다. 마지막으로 각각의 문항 간 신뢰도 지수는 .69 .88로 나타났으며, 총 신뢰도는 .891로 본 연구에서 활 용된 차별적 정서 척도의 탐색적 요인분석은 타당한 것으 로 확인되었다.

\section{조절초점 척도의 타당도 및 신뢰도 검증 결과}

선수들의 조절 초점 유형을 측정하기 위하여 Higgins (1997)의 자기차이이론을 토대로 스포츠 상황에 서 활용 가능성을 검증한 Hong(2005)의 자기 조절초점 척도(self-regulatory focus scale)를 활용하였다. 자기 조절초점 척도는 이상적 자기를 갖기 위한 향상 초점 (8개 문항)과 의무적 자기를 갖는 예방 초점 (7개 문항)의 2 개 하위요인의 총 15 개 문항으로 구성되어 있으며, 5 점 리 커트로 반응하도록 제시하고 있다. 탐색적 요인분석 결과 는 아래〈Table 3 〉과 같다.

〈Table 3〉에 나타난 결과와 같이 사격 선수들이 경험 하는 동기는 선행연구와 동일하게 2개요인(향상초점, 예 방초점)의 11 문항으로 나타났다.

또한 Bartlett의 단위행렬검증결과 $p<.05$ 의 유의한 통 계적 유의수준을 보여줌으로써 잠재변수의 다중상관은 검증되었으며, Kiser-Meyer-Olkin의 표준적합도 수치 또한 .844로 나타났다.

또한 이들 2 개 요인의 총 설명변량은 $47 \%$ 를 설명하고 있으며, 도출된 각 요인의 요인 부하량은 .41 .87를 나 타내었다. 마지막으로 각각의 문항 간 신뢰도 지수는 .88 .91로 나타났으며, 총 신뢰도는 .897로 본 연구에 
Table 3. Results of exploratory factor analysis and reliability verification on the regulatory focus scale

\begin{tabular}{ccc}
\hline \hline \multirow{2}{*}{$\begin{array}{c}\text { questionnaire } \\
\text { item }\end{array}$} & \multicolumn{2}{c}{ Name of factor \& Factor loadings } \\
\cline { 2 - 3 } Q14 & promotion focus & prevention focus \\
Q15 & .794 & -.026 \\
Q18 & .756 & -.062 \\
Q17 & .699 & .091 \\
Q16 & .660 & .078 \\
Q2 & .583 & -.049 \\
Q7 & .004 & .874 \\
Q9 & .047 & .750 \\
Q4 & -.031 & .674 \\
Q13 & .057 & .472 \\
Q1 & .037 & .429 \\
\hline eigen & -.100 & .414 \\
\hline value & 5.353 & 3.271 \\
\hline \% of variable & 29.73 & 18.17 \\
\hline cumulative variable & 29.73 & 47.90 \\
\hline Cronbach's alpha & .910 & .887 \\
\hline Kaiser-Meyer-Olkin(KMO) & .844 \\
\hline Bartlett's test & $p<.05^{*}, p<.01 * *, p<.001^{* * *}$ \\
\hline \hline & & $1614.442^{* * *}$ \\
\hline
\end{tabular}

서 활용된 조절초점 동기 척도의 탐색적 요인분석은 타당 한 것으로 확인되었다.

\section{훈련관여 척도의 타당도 및 신뢰도 검증 결과}

사격 선수들의 훈련관여 수준을 측정하기 위하여 Lee 와 Jang(2010)의 연구에서 구조화시킨 학습관여 개념을 토대로 Seong, et, al.,(2015)이 스포츠 상황에서 활용할 수 있도록 타당화한 훈련관여 척도(training engagement scale; TES)를 사용하였다. 이 척도는 4요인 16 문항으 로 구성되어 있으며, 5점 리커트 반응 방식을 활용하여 '전혀 아니다'의 1점부터 '매우 그렇다'의 5점까지 반응토 록 되어 있고, 점수가 높을수록 훈련관여 수준이 높음을 의미한다. 훈련관여 척도가 이 연구에서도 타당한지를 알 아보기 위해 탐색적 요인분석과 신뢰도 분석을 실시하였 다.

〈Table 4〉에 나타난 결과와 같이 사격 선수들이 지각 하는 훈련관여 척도에 대한 탐색적 요인분석 결과 선행연
Table 4. Results of exploratory factor analysis and reliability verification of the training engagement scale

\begin{tabular}{|c|c|c|c|c|}
\hline \multirow{2}{*}{$\begin{array}{l}\text { questionnaire } \\
\text { item }\end{array}$} & \multicolumn{4}{|c|}{ Name of factor \& Factor loadings } \\
\hline & $\begin{array}{l}\text { emotional } \\
\text { engagement }\end{array}$ & $\begin{array}{l}\text { cognitive } \\
\text { engagement }\end{array}$ & $\begin{array}{c}\text { leading } \\
\text { engagement }\end{array}$ & $\begin{array}{l}\text { behavioral } \\
\text { engagement }\end{array}$ \\
\hline Q5 & .854 & .083 & .071 & -.024 \\
\hline Q7 & .820 & -.009 & .033 & -.016 \\
\hline Q8 & .742 & -.050 & -.048 & .093 \\
\hline Q6 & .673 & -.087 & .088 & -.096 \\
\hline Q1 & -.017 & .818 & -.044 & .045 \\
\hline Q2 & .001 & .762 & .035 & .110 \\
\hline Q3 & .002 & .655 & .110 & -.040 \\
\hline Q4 & .257 & .554 & .035 & -.021 \\
\hline Q14 & -.011 & .103 & .801 & .148 \\
\hline Q15 & -.039 & -.199 & .747 & -.042 \\
\hline Q16 & .100 & -.136 & .636 & -.113 \\
\hline Q13 & .151 & .066 & .394 & .162 \\
\hline Q11 & -.046 & -.093 & .079 & .814 \\
\hline Q10 & .298 & -.185 & -.072 & .367 \\
\hline Q12 & .167 & .025 & .223 & .342 \\
\hline $\begin{array}{l}\text { eigen } \\
\text { value }\end{array}$ & 6.774 & 1.577 & 1.274 & 1.016 \\
\hline$\%$ of variable & 42.340 & 9.855 & 7.963 & 6.353 \\
\hline $\begin{array}{c}\text { cumulative } \\
\text { variable }\end{array}$ & 42.340 & 52.195 & 60.158 & 66.511 \\
\hline $\begin{array}{l}\text { Cronbach's } \\
\text { alpha }\end{array}$ & .871 & .840 & .788 & .678 \\
\hline \multicolumn{3}{|c|}{ Kaiser-Meyer-Olkin(KMO) } & \multicolumn{2}{|c|}{.899} \\
\hline \multicolumn{3}{|c|}{ Bartlett's test } & \multicolumn{2}{|c|}{$1727.159^{* * *}$} \\
\hline
\end{tabular}

구와 동일하게 4개 요인(정서적 관여, 인지적 관여, 주도 적 관여, 행동적 관여)의 15 문항으로 나타났다.

Bartlett의 단위행렬검증결과 $p<.05$ 의 유의한 통계적 유의수준을 보여줌으로써 잠재변수의 다중상관은 검증 되었으며, Kiser-Meyer-Olkin의 표준적합도 수치치는 .899로 나타났다.

또한 이들 4 개 요인의 총 설명변량은 $66 \%$ 를 설명하 고 있으며, 도출된 각 요인의 요인 부하량은 .34 .85를 나타내었다. 마지막으로 각각의 문항 간 신뢰도 지수는 .67 .87로 나타났으며, 총 신뢰도는 .864로 본 연구에 서 활용된 훈련관여 척도는 타당한 것으로 확인되었다. 


\section{자료 처리}

본 연구의 자료 분석 절차는 다음과 같다.

첫째, 엘리트 사격 선수들의 정서 경험과 동기 척도의 구인타당도 검증을 위하여 주축요인분석 (principle axis factoring)과 사각회전(oblique rotation)방식의 직접 오 블리민(direct oblimin)을 활용한 탐색적 요인분석 (EFA: exploratory factor analysis)을 적용하여 1차 요 인 구조를 알아보았다. 또한 탐색된 하위 문항들에 대한 신뢰도 분석(내적일치도)을 위해 Cronbach's Alpha 계 수를 산출하여 문항 간 일치성을 알아보았다.

둘째, 엘리트 사격 선수들이 지각하는 정서와 조절초 점 및 훈련관여의 수준을 알아보기 위하여 평균 및 표준 편차의 기초 통계치를 산출하였다.

셋째, 엘리트 사격 선수들이 지각하는 정서와 조절초 점 및 훈련관여의 관계를 알아보기 위하여 상관분석 (correlation analysis)을 수행하였으며, 상관분석을 기 초로 다중회귀 분석(multiple regression analysis )을 통해 각각 변수 간 인과관계를 알아보았다.

넷째, 긍정적, 부정적 정서에 따라 조절초점과 훈련관 여의 흐름을 알아보기 위하여 경로분석(path analysis) 을 실시하였다.

\section{연구 결과}

\section{차별적 정서와 조절초점 및 훈련관여의 기초 통계치}

타당도가 검증된 차별적 정서와 조절초점 및 훈련관여 에 대한 사격 선수들의 지각 수준을 알아보기 위하여 변 수들의 기초 통계치를 산출하였다. 결과는 아래〈Table 5)와 같다.

〈Table 5〉에 제시된 바와 같이 두 척도의 기초 통계치 를 산출한 결과 차별적 정서는 즐거움 정서가 가장 높았고 이후 흥미와 놀람, 불안, 분노, 죄책감 순으로 나타났으며 마지막으로 혐오 정서가 가장 낮은 수치를 보였다. 즉, 엘 리트 사격 선수들은 시합 중 즐거움, 흥미와 같은 긍정 정 서를 가장 빈번히 경험하는 반면 혐오, 분노와 같은 부정 적 정서는 비교적 낮게 경험하는 것으로 나타났다. 또한, 동기의 경우 향상초점, 예방초점의 순으로 나타났다. 마지 막으로 엘리트 사격 선수들의 훈련 관여는 인지적 관여 수
Table 5. Basic statistics of discriminatory sentiments and control focus and training involvement

\begin{tabular}{|c|c|c|c|}
\hline Name of factor & factor & Mean & $\begin{array}{l}\text { Standard } \\
\text { deviation }\end{array}$ \\
\hline \multirow{7}{*}{$\begin{array}{l}\text { discriminatory } \\
\text { emotions }\end{array}$} & Anxiety & 2.37 & 1.12 \\
\hline & surprise & 3.55 & .85 \\
\hline & disgust & 1.59 & .80 \\
\hline & anger & 2.32 & .98 \\
\hline & enjoyment & 3.73 & .84 \\
\hline & guilt & 2.64 & 1.10 \\
\hline & interest. & 3.62 & .75 \\
\hline \multirow{2}{*}{$\begin{array}{l}\text { regulatory } \\
\text { focus }\end{array}$} & promotion focus & 3.79 & .67 \\
\hline & prevention focus & 3.03 & .78 \\
\hline \multirow{4}{*}{$\begin{array}{c}\text { training } \\
\text { engagement }\end{array}$} & $\begin{array}{l}\text { emotional } \\
\text { engagement }\end{array}$ & 3.83 & .74 \\
\hline & $\begin{array}{l}\text { cognitive } \\
\text { engagement }\end{array}$ & 3.86 & .63 \\
\hline & $\begin{array}{c}\text { leading } \\
\text { engagement }\end{array}$ & 3.61 & .73 \\
\hline & $\begin{array}{l}\text { behavioral } \\
\text { engagement }\end{array}$ & 3.41 & .75 \\
\hline
\end{tabular}

준이 가장 높았으며, 행동적 관여가 가장 낮았다.

\section{차별적 정서와 조절초점 및 훈련관여의 상관분석}

엘리트 사격 선수들이 경험하는 차별적 정서가 조절초 점 동기와 어떤 관계가 있는지를 살펴보기 위하여 상관분 석을 실시하였으며 그 결과는 〈Table 6)과 같다.

분석결과 차별적 정서와 조절초점 간에는 유의미한 상관이 있는 것으로 나타났다. 먼저 놀람, 즐거움, 흥미 요인은 향상초점과 정적 관계를 보였으며 분노, 죄책감 요인은 예방초점과 정적 관계로 나타났다.

또한, 불안, 혐오 요인은 향상초점과는 부적 상관관계 를 보였으며 예방초점과는 정적 상관이 있었다. 또한 훈 련 관여는 불안이나 혐오 등과 같은 부정정서와는 부적 상관관계를 보였으나, 놀람이나 즐거움과 같은 긍정 정 서와는 정적 상관 관계를 보였다. 즉, 사격 선수들이 시 합 중 경험하는 놀람, 즐거움, 흥미와 같은 긍정 정서는 향상초점을 증가시키는 요인이지만 반대로 불안, 혐오와 같은 부정적 정서들은 향상초점을 오히려 감소시키고 있 었으며 이와 동시에 예방초점을 증가시키는 요인이었다. 또한, 분노와 죄책감 역시 예방초점에 영향을 주는 부정 
적 정서임을 확인하였으며, 훈련관여 역시 긍정과 부정 의 정서 유형에 따라 정적, 부적 관계를 보이는 것으로 확인되었다.

\section{차별적 정서와 조절초점의 다중회귀분석}

연구에서 설정한 경로를 기반으로 차별적 정서가 조절
초점에 어떠한 영향을 미치는지 알아보고 또한 조절초점 이 훈련관여에 어떠한 영향을 미치는지 살펴보기 위하여 다중회귀분석을 수행하였다.

분석결과는 〈Table 7〉과 같다. 예측력을 기초로 결과 를 제시하면 먼저 즐거움 $\left(\mathrm{R}^{2}=10.6 \%\right)$ 과 흥미 $\left(\mathrm{R}^{2}=\right.$ $2.1 \%)$ 는 향상초점에 긍정적 영향을 미치는 것으로 나타 났으나 혐오 $\left(\mathrm{R}^{2}=2.8 \%\right)$ 는 향상초점에 부정적 영향을 미

Table 6. Correlation between discriminatory emotions and regulatory focus and training engagement

\begin{tabular}{|c|c|c|c|c|c|c|c|c|c|c|c|c|c|}
\hline factor & Anxiety & surprise & disgust & anger & $\begin{array}{l}\text { enjoy } \\
\text { ment }\end{array}$ & guilt & interest. & $\begin{array}{l}\text { promotion } \\
\text { focus }\end{array}$ & $\begin{array}{l}\text { prevention } \\
\text { focus }\end{array}$ & $\begin{array}{l}\text { emotional } \\
\text { engagement }\end{array}$ & $\begin{array}{c}\text { cognitive } \\
\text { engagement }\end{array}$ & $\begin{array}{c}\text { leading } \\
\text { engagemen }\end{array}$ & $\begin{array}{l}\text { behavioral } \\
\text { engagemen }\end{array}$ \\
\hline anxiety & 1 & & & & & & & & & & & & \\
\hline surprise & $-.174 * *$ & 1 & & & & & & & & & & & \\
\hline disgust & $.436^{* *}$ & -.038 & 1 & & & & & & & & & & \\
\hline anger & $.547^{* *}$ & -.076 & $.596^{* *}$ & 1 & & & & & & & & & \\
\hline enjoyment & $-.244 * *$ & $.471 * *$ & $-.276^{* *}$ & $-.213^{* *}$ & 1 & & & & & & & & \\
\hline guilt & $.682 * *$ & -.090 & $.362 * *$ & $.518^{* *}$ & $-.141^{*}$ & 1 & & & & & & & \\
\hline interest & $-.273 * *$ & $.497 * *$ & $-.193 * *$ & $-.212 * *$ & $.578^{* *}$ & $-.184 * *$ & 1 & & & & & & \\
\hline $\begin{array}{l}\text { promotion } \\
\text { focus }\end{array}$ & $-.168^{*}$ & $.258^{* *}$ & $-.252 * *$ & -.130 & $.326^{* *}$ & -.076 & $.314 * *$ & 1 & & & & & \\
\hline $\begin{array}{l}\text { prevention } \\
\text { focus }\end{array}$ & $.576^{* *}$ & .001 & $.322 * *$ & $.460^{* *}$ & -.070 & $.570^{* *}$ & -.051 & .031 & 1 & & & & \\
\hline $\begin{array}{l}\text { emotional } \\
\text { engagement }\end{array}$ & $-.243 * *$ & $.412 * *$ & $-.285^{* *}$ & $-.250^{* *}$ & $.456^{* *}$ & -.105 & $.394 * *$ & $.450 * *$ & -.075 & 1 & & & \\
\hline $\begin{array}{l}\text { cognitive } \\
\text { engagement }\end{array}$ & $-.248 * *$ & $.185^{* *}$ & $-.167^{*}$ & -.102 & $.357^{* *}$ & $-.141^{*}$ & $.416^{* *}$ & $.466^{* *}$ & -.104 & $.564 * *$ & 1 & & \\
\hline $\begin{array}{l}\text { leading } \\
\text { engagement }\end{array}$ & $-.191 * *$ & $.377^{* *}$ & $-.140^{*}$ & -.106 & $.445^{* *}$ & -.045 & $.371 * *$ & $.340^{* *}$ & .036 & $.552 * *$ & $.431^{* *}$ & 1 & \\
\hline $\begin{array}{l}\text { behavioral } \\
\text { engagement }\end{array}$ & $-.140 *$ & $.346^{* *}$ & -.075 & $-.170^{*}$ & $.269^{* *}$ & -.112 & $.282 * *$ & $.284^{* *}$ & -.017 & $.565^{* *}$ & $.466^{* *}$ & $.481^{* *}$ & 1 \\
\hline
\end{tabular}

Table 7. Summary of analysis results of multiple reversals of discriminatory sentiments, regulatory focus and training engagement

\begin{tabular}{|c|c|c|c|c|c|}
\hline $\begin{array}{l}\text { quasi-marginant } \\
\text { variable }\end{array}$ & Prophecy variable & $\mathrm{R}^{2}$ & $\mathrm{R}^{2 \mathrm{C}}$ & Beta & $\mathrm{t}$ \\
\hline \multirow{3}{*}{ promotion focus } & enjoyment & .106 & .106 & .176 & $2.285^{*}$ \\
\hline & disgust & .135 & .028 & -.169 & $-2.644 * *$ \\
\hline & interest & .156 & .021 & .180 & $2.388^{*}$ \\
\hline \multirow{4}{*}{ prevention focus } & anxiety & .332 & .332 & .327 & $4.384 * * *$ \\
\hline & guilt & .390 & .059 & .288 & $4.001^{* * *}$ \\
\hline & anger & .404 & .014 & .158 & $2.517^{*}$ \\
\hline & interest & .419 & .014 & -124 & $2.338^{*}$ \\
\hline emotional engagement & promotion focus & .202 & .202 & .450 & $7.573 * * *$ \\
\hline \multirow{2}{*}{ cognitive engagement } & promotion focus & .214 & .217 & .470 & $8.036^{* * *}$ \\
\hline & prevention focus & .225 & .014 & -.119 & $-2.031 * * *$ \\
\hline leading engagement & promotion focus & .116 & .116 & .340 & $5.436^{* * *}$ \\
\hline behavioral engagement & promotion focus & .081 & .081 & .284 & $4.454 * * *$ \\
\hline
\end{tabular}


치는 것으로 나타났다. 또한 예방초점의 경우 불안 $\left(\mathrm{R}^{2}=\right.$ $33.2 \%)$ 과 죄책감 $\left(\mathrm{R}^{2}=5.9 \%\right)$ 및 분노 $\left(\mathrm{R}^{2}=1.4 \%\right)$ 의 순 서로 예방초점에 긍정적 영향을 미치는 것으로 나타났으 나 흥미 $\left(\mathrm{R}^{2}=1.4 \%\right)$ 정서는 예방초점에 부정적 영향을 미치는 것으로 나타났다.

또한 훈련관여에 영향을 미치는 조절초점을 알아본 결 과 먼저 정서적 관여 $\left(\mathrm{R}^{2}=20.2 \%\right)$ 와 인지적 관여 $\left(\mathrm{R}^{2}=\right.$ $21.7 \%)$, 주도적 관여 $\left(\mathrm{R}^{2}=11.6 \%\right)$, 행동적 관여 $\left(\mathrm{R}^{2}=\right.$ $21.7 \%)$ 에 영향을 미치는 조절 초점은 향상 초점으로 나 타났으나, 인지적 관여에는 예방초점 $\left(\mathrm{R}^{2}=-1.4 \%\right)$ 이 부 정적 영향을 미치는 것으로 나타났다.

\section{시합 정서와 조절초점 및 훈련관여의 경로분석}

엘리트 사격 선수가 경험하는 시합에 따른 정서와 조 절초점 및 훈련관여의 관계를 알아보기 위하여 정서 $\rightarrow$ 조 절초점 $\rightarrow$ 훈련관여의 경로분석을 실시하였다. 경로분석 은 서로 대비되는 긍정과 부정 정서를 구분하고 분석하여 각각의 경로를 확인하여 제시하였다.

\section{1) 긍정정서와 조절초점 및 훈련관여의 경로분석}

긍정정서에 따른 조절초점 및 훈련관여의 경로분석 결 과와 경로분해 결과는 〈Figure 1〉과 〈Table 8〉과 같다.

〈Figure 1〉과〈Table 8〉에 제시된 바와 같이 즐거움과 흥미 정서는 향상초점을 강화시켜 훈련관여에 영향을 미 치는 것으로 나타났다. 예방초점과는 유의한 경로가 나타 나지 않았으며, 예방초점은 훈련관여에 영향을 미치지 않 았다. 즉 시합에 따른 긍정정서는 향상초점을 강화시켜 훈련관여에 영향을 미친다는 것을 확인할 수 있었다.

\section{2) 부정정서와 조절초점 및 훈련관여의 경로분석}

부정정서에 따른 조절초점 및 훈련관여의 경로분석 결 과와 경로분해 결과는 〈Figure 2〉와 〈Table 9〉와 같다. 〈Figure 2〉와 〈Table 9〉에 제시된 바와 같이 시합을 앞둔 상황에서 경험하는 불안과 혐오 정서는 향상초점을 감소 시키고, 불안은 예방초점을 증가시키는 것으로 나타났으 며, 분노 정서는 예방초점을 증가시키는 것으로 나타났 다. 또한 부정적 정서에 따른 예방 초점은 인지적 관여도 를 감소시키는 것으로 나타났다.
Table 8 . The regulatory focus on positive emotion and the disassembly of the training engagement

\begin{tabular}{|c|c|c|c|c|c|c|}
\hline $\begin{array}{l}\text { independent } \\
\text { variable }\end{array}$ & Path & $\begin{array}{l}\text { dependent } \\
\text { variable }\end{array}$ & Estimate & S.E. & C.R. & $\mathrm{P}$ \\
\hline surprise & $\rightarrow$ & $\begin{array}{l}\text { promotion } \\
\text { focus }\end{array}$ & .070 & .049 & 1.426 & .154 \\
\hline surprise & $\rightarrow$ & $\begin{array}{l}\text { prevention } \\
\text { focus }\end{array}$ & .048 & .060 & .797 & .426 \\
\hline enjoyment & $\rightarrow$ & $\begin{array}{l}\text { promotion } \\
\text { focus }\end{array}$ & .155 & .050 & 3.127 & .002 \\
\hline enjoyment & $\rightarrow$ & $\begin{array}{l}\text { prevention } \\
\text { focus }\end{array}$ & -.070 & .062 & -1.131 & .258 \\
\hline interest & $\rightarrow$ & $\begin{array}{l}\text { promotion } \\
\text { focus }\end{array}$ & .142 & .055 & 2.571 & .010 \\
\hline interest & $\rightarrow$ & $\begin{array}{l}\text { prevention } \\
\text { focus }\end{array}$ & -.035 & .069 & -.516 & .606 \\
\hline $\begin{array}{l}\text { promotion } \\
\text { focus }\end{array}$ & $\rightarrow$ & $\begin{array}{l}\text { emotional } \\
\text { engagement }\end{array}$ & .495 & .067 & 7.418 & $* * *$ \\
\hline $\begin{array}{l}\text { promotion } \\
\text { focus }\end{array}$ & $\rightarrow$ & $\begin{array}{c}\text { cognitive } \\
\text { engagement }\end{array}$ & .439 & .056 & 7.807 & $* * *$ \\
\hline $\begin{array}{l}\text { promotion } \\
\text { focus }\end{array}$ & $\rightarrow$ & $\begin{array}{c}\text { leading } \\
\text { engagement }\end{array}$ & .369 & .070 & 5.256 & $* * *$ \\
\hline $\begin{array}{l}\text { promotion } \\
\text { focus }\end{array}$ & $\rightarrow$ & $\begin{array}{c}\text { behavioral } \\
\text { engagement }\end{array}$ & .319 & .074 & 4.329 & $* * *$ \\
\hline $\begin{array}{l}\text { prevention } \\
\text { focus }\end{array}$ & $\rightarrow$ & $\begin{array}{l}\text { emotional } \\
\text { engagement }\end{array}$ & -.084 & .056 & -1.505 & .132 \\
\hline $\begin{array}{l}\text { prevention } \\
\text { focus }\end{array}$ & $\rightarrow$ & $\begin{array}{c}\text { cognitive } \\
\text { engagement }\end{array}$ & -.096 & .053 & -1.814 & .070 \\
\hline $\begin{array}{l}\text { prevention } \\
\text { focus }\end{array}$ & $\rightarrow$ & $\begin{array}{l}\text { leading } \\
\text { engagement }\end{array}$ & .024 & .059 & .415 & .678 \\
\hline $\begin{array}{l}\text { prevention } \\
\text { focus }\end{array}$ & $\rightarrow$ & $\begin{array}{l}\text { behavioral } \\
\text { engagement }\end{array}$ & -.025 & .062 & -.405 & .685 \\
\hline
\end{tabular}

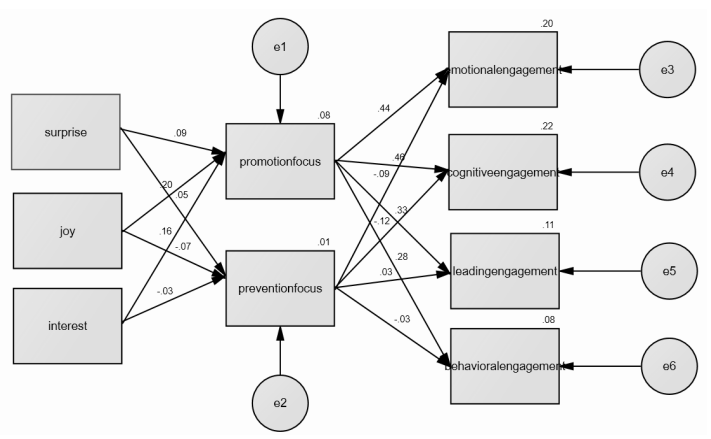

Fig. 1. Path analysis of research variables according to positive emotion 


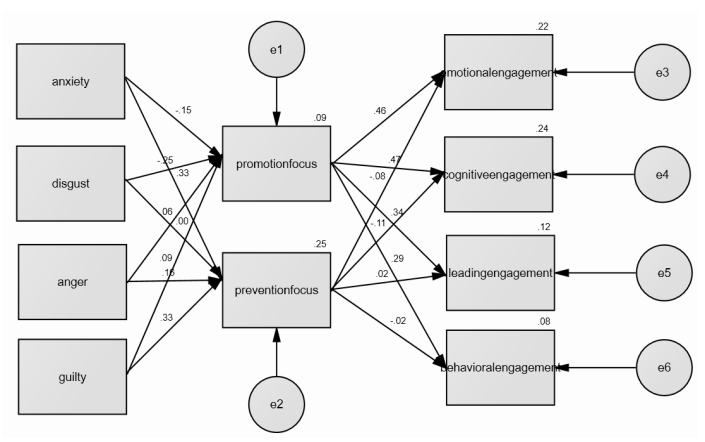

Fig. 2. Path analysis of research variables according to negative emotion

Table 9. The regulatory focus on negative emotion and the disassembly of the training engagement

\begin{tabular}{|c|c|c|c|c|c|c|}
\hline $\begin{array}{l}\text { independent } \\
\text { variable }\end{array}$ & Path & $\begin{array}{l}\text { dependent } \\
\text { variable }\end{array}$ & Estimate & S.E. & C.R. & $\mathrm{P}$ \\
\hline anxiety & $\rightarrow$ & $\begin{array}{l}\text { promotion } \\
\text { focus }\end{array}$ & -.089 & .038 & -2.315 & .021 \\
\hline anxiety & $\rightarrow$ & $\begin{array}{l}\text { prevention } \\
\text { focus }\end{array}$ & 207 & .036 & 5.793 & $* * *$ \\
\hline disgust & $\rightarrow$ & $\begin{array}{l}\text { promotion } \\
\text { focus }\end{array}$ & -.212 & .054 & -3.957 & $* * *$ \\
\hline disgust & $\rightarrow$ & $\begin{array}{l}\text { prevention } \\
\text { focus }\end{array}$ & 000 & .050 & .001 & .999 \\
\hline anger & $\rightarrow$ & $\begin{array}{l}\text { promotion } \\
\text { focus }\end{array}$ & .039 & .044 & .883 & .377 \\
\hline anger & $\rightarrow$ & $\begin{array}{l}\text { prevention } \\
\text { focus }\end{array}$ & .116 & .041 & 2.861 & .004 \\
\hline guilt & $\rightarrow$ & $\begin{array}{l}\text { promotion } \\
\text { focus }\end{array}$ & .053 & .039 & 1.362 & .173 \\
\hline guilt & $\rightarrow$ & $\begin{array}{l}\text { prevention } \\
\text { focus }\end{array}$ & .206 & .036 & 5.693 & $* * *$ \\
\hline $\begin{array}{l}\text { promotion } \\
\text { focus }\end{array}$ & $\rightarrow$ & $\begin{array}{l}\text { emotional } \\
\text { engagement }\end{array}$ & .495 & .064 & 7.757 & $* * *$ \\
\hline $\begin{array}{l}\text { promotion } \\
\text { focus }\end{array}$ & $\rightarrow$ & $\begin{array}{c}\text { cognitive } \\
\text { engagement }\end{array}$ & .439 & .054 & 8.163 & $* * *$ \\
\hline $\begin{array}{l}\text { promotion } \\
\text { focus }\end{array}$ & $\vec{t}$ & $\begin{array}{c}\text { leading } \\
\text { engagement }\end{array}$ & .369 & .067 & 5.496 & $* * *$ \\
\hline $\begin{array}{l}\text { promotion } \\
\text { focus }\end{array}$ & $\rightarrow$ & $\begin{array}{l}\text { behavioral } \\
\text { engagement }\end{array}$ & .319 & .070 & 4.526 & $* * *$ \\
\hline $\begin{array}{l}\text { prevention } \\
\text { focus }\end{array}$ & $\rightarrow$ & $\begin{array}{l}\text { emotional } \\
\text { engagement }\end{array}$ & -.084 & .063 & -1.336 & .182 \\
\hline $\begin{array}{l}\text { prevention } \\
\text { focus }\end{array}$ & $\overrightarrow{\mid}$ & $\begin{array}{l}\text { cognitive } \\
\text { engagement }\end{array}$ & -.096 & .047 & -2.043 & .041 \\
\hline $\begin{array}{l}\text { prevention } \\
\text { focus }\end{array}$ & $\rightarrow$ & $\begin{array}{c}\text { leading } \\
\text { engagement }\end{array}$ & .024 & .066 & .368 & .713 \\
\hline $\begin{array}{l}\text { prevention } \\
\text { focus }\end{array}$ & 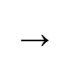 & $\begin{array}{l}\text { behavioral } \\
\text { engagement }\end{array}$ & -.025 & .069 & -.360 & .719 \\
\hline
\end{tabular}

\section{논 의}

개인이 처한 상황에 따라 정서가 어떻게 변화하는지 알아보는 연구들은(Gondola \& Tuckman, 1982; Gustafsson, 2012) 정서의 유인가 이론을 토대로 정서 를 긍정과 부정으로 구분하여 정서가 파생하는 역할에 대 하여 논의하였다. 여기서 부정정서를 보통 경험하고 싶지 않은 정서로 간주하지만 정서의 기능을 강조하는 기능주 의 입장에 따르면 부정정서는 진화과정에서 인류가 환경 에 적응하여 생존하기 위한 필요에서 생겼다고 한다 (Buss, 2000).

반면에 긍정정서가 삶에 활력을 불어넣고 회복시켜 주 는 역할을 한다면 부정정서는 환경의 위협과 위험에서 보 호해 주는 역할을 한다(Jo, 1995). 생존이라는 측면에서 보면 긍정정서와 부정정서 모두 중요하다는데 동의하며, 정서의 수를 보더라도 얼굴표정을 기준으로 부정정서는 긍정정서보다 2배 정도 많고(Ekman \& Friesen, 1975), 파생 단어를 비교해 보면 부정정서가 긍정정서보 다 약 3배 정도 더 많다(Shaver et al., 1987; Heo \& $\mathrm{Oh}, 2014)$. 따라서 긍정정서와 부정정서의 역할과 관련 해서는 어느 정서가 “옳다”는 해석은 상당한 오류를 야기 할 수 있다는 측면에서 해석의 상당한 노력이 필요하다. 그러나 정서와 관련된 연구(Lazarus, 1991; Yoo, 2012 , Seong \& Park, 2016)들은 긍정적 정서는 개인의 동기 를 자극하여 행동에 긍정적 영향을 미치지만, 부정적 정 서는 개인의 동기를 약화시키고 후속 행동에 부정적 영향 을 미친다는 연구결과들을 발표하였다.

이러한 선행연구의 내용을 기초로 본 연구는 엘리트 사격 선수들이 시합 시 경험하는 정서 유형에 따른 조절 초점과 훈련관여의 관계를 알아봄으로써 정서와 동기 및 행동의 인과적 경로를 알아보기 위한 목적으로 수행되었 다. 이에 엘리트 사격 선수 228 명을 대상으로 차별적 정 서와 조절초점 및 훈련관여 측정도구를 활용하여 자료를 수집하였으며 연구절차에 따라 분석하여 나타난 결과를 논의하면 다음과 같다.

본 연구는 시합 중 경험하는 정서의 유형이 조절초점 에 영향을 주는 것으로 나타났다. 특히 차별적 정서 중에 서도 즐거움, 흥미와 같은 긍정적 측면에 놓인 정서들은 보다 과제 성공에 도달하고자 하는 향상초점을 자극하였 으며 반면 혐오와 같은 부정적 정서는 오히려 향상초점을 저해하여 시합에 성공하거나 시합에 우승하겠다는 등의 
동기를 저하시키고 있었다. 또한, 불안, 죄책감, 분노 등 의 부정적 정서들은 피할 수 없는 실패상황을 회피하려는 예방초점을 자극하여 시합상황에 보다 능동적으로 대처 하지 못하도록 하고 있었다. 결론적으로 긍정 유형의 정 서들은 향상초점을 자극하거나 예방초점을 저해하는 반 면, 부정 유형의 정서들은 예방초점을 자극하고 있었다.

이러한 정서와 조절초점 간의 유의미한 관계는 다양한 연구를 통해 알려져 왔다. 선수들의 향상초점이 긍정 정 서와 관련이 있고, 예방초점이 부정 정서와 관계가 있음 을 보고한 Adie 등(2010)의 연구를 포함하여, 시합 중의 긍정적 정서의 경험이 선수의 경기력을 향상시킨다는 Gustafsson(2012)의 연구 그리고 긍정적 정서의 경험이 선수의 심리적 안정성을 부여한다는 Gondola와 Tuckman(1982)의 연구를 통해 이를 확인할 수 있다.

특히 정서의 발현은 동기, 자기효능감과 같은 다른 요 소와 함께 상호작용하는데(Jones et, al., 2009; Hwang $\&$ Park, 2014), 안정적 수행이나 성공 혹은 불안정한 수 행이나 실패로 인한 과거 경험과 시합에 대한 자기 평가 가 선수들의 정서의 방향을 결정한다고 볼 수 있다.

이와 관련해 Nicholls et. al(2012)은 시합에 대한 선 수의 정서와 조절초점의 관계를 설명하면서, 시합에 대한 스트레스와 같이 시합을 부정적으로 인식할수록 부정 정 서를 유발시켜 시합 상황을 회피하려는 전략을 선택함을 설명한 바 있다.

이러한 정서와 동기의 관계는 조절초점 이론을 통해 설명할 수 있으며, 조절초점은 정서 경험에 따른 인지적 처리과정에 영향을 미친다. Higgins(1987, 1997, $1998,2001)$ 가 수행한 조절초점과 정서의 관계 연구와 조절 초점의 역할을 탐색한 연구들(Brenninkmeijer \& Hekkert-Koning, 2015; Pondman, 2015; Pham \& Chang 2010; Strauman, 1989; Strauman \& Higgins, 1987, 1989; Hamstra, Bolderdijk \& Veldstra, 2011: Seong \& Park, 2016)의 결과에 따르면 개인이 처한 상 황에 대해 어떤 정서로 반응하느냐에 따라 후속 행동이 달라진다고 설명한다(Lazarus, 1991; Yoo, 2012, Seong \& Park, 2016). 즉, 선수들이 시합이나 과제 상 황에서 이를 어떻게 판단하고 어떤 정서를 경험하느냐에 따라 시합에 대한 다른 반응이 일어난다는 것이다.

따라서 시합상황에서 긍정적 정서를 경험할수록 선수 들은 보다 격발을 잘 하기 위한 향상초점을 자극함으로써 시합에 대한 훈련 관여 행동이 강화되거나 증가될 수 있
다는 근거를 제공하고 반대로 부정적 정서를 경험할수록 이 상황을 소극적으로 넘기기 위한 반응으로 예방초점이 발현되어 훈련관여 행동을 약회시키거나 감소시킬 수 있 다는 가설을 본 연구의 결과를 통해 확인할 수 있었다. 결 국, 정서는 선수의 다음 목표나 전략 및 동기에 영향을 미 치고 이후 수행에 영향을 주기에(Moon et. al., 2009), 경기 전반에 걸친 선수의 정서를 어떻게 조절하느냐는 경 기력을 조절하는 중요한 심리적 요인이 된다고 해석 할 수 있다. 이와 관련하여 시합에 대한 정서를 연구한 Hanin(2004)은 시합 상황에서 선수들이 경험한 정서가 시합에 지대한 영향을 미친다고 설명하고 있다. 또한 이 러한 과정에서 정서가 수행에 어떠한 영향을 미치는지 그 과정을 규명하는 것이 중요하다고 설명하였다. 따라서 경 기 중 예측되지 않는 상황으로 인한 스트레스와 평가는 부정적 정서를 발현하고 수행에 영향을 미치며 (Dugdale, Ekland와 Gordon, 2002; McCarthy, 2011), 과거 과제에 대한 실패와 성공의 경험이 정서적 반응으로 이어져 역동적으로 반응한다(Higgins, 1987) 는 연구 결과에 비추어 볼 때 과거 반복된 시합의 성패 경 험과 그로 인한 현재 시합의 인식이 경기 중의 정서와 동 기에 영향을 주는 것으로 볼 수 있다. 특히 본 연구에서 나타난 연구결과에서는 시합에 대한 정서와 조절초점 및 훈련관여의 관계 경로는 시합을 조절하는 일련의 자기조 절 과정으로 이해할 수 있다(Park, 2012).

또한 조절초점과 관여의 관계를 연구한 Choi 등 (2011)과 $\operatorname{Yun}(2016)$ 및 $\operatorname{Kim}(2012)$ 등의 연구에서는 향상초점과 예방초점이 긍정과 부정의 위치에서 설명되 지 않을 수 있다는 근거를 제시하였다. 상황 인식에 대한 배타적 결정인 예방초점은 결국은 개인이 스스로를 보호 하기 위한 전략으로 활용되기에 어떠한 조절초점 요인이 관여도에 긍정적인 영향을 미친다고 일관성 있는 결과를 보고하지 못하였다. 그러나 조절초점과 관련된 일련의 연 구들은 예방초점이 긍정적 심리요인의 약화 및 감소를 야 기한다는 결과에 동의하고 있다. 따라서 본 연구에서의 예방초점은 긍정적 정서와 훈련관여의 경로를 매개하는 데는 그 역할이 규명되지 않았으나, 부정적 정서를 통한 경로에서는 일부 경로가 유의하게 나타났다. 즉 불안은 예방초점을 강화시키고 강화된 회피 초점은 인지적 관여 를 약화시키는 것으로 나타났다. 이러한 결과는 조절초점 과 관여의 관계를 검증한 선행연구의 두 가지 관점을 모 두 수용하는 결과로 나타났다. 
결국 시합에 따른 엘리트 사격 선수들의 정서와 자기 조절 초점은 상호 유기적으로 작용하고 있었고, 시합 상 황에서 안정적인 심리 유지와 후속 행동의 강화를 위해서 는 경기 전 혹은 시합 초기 선수가 보다 긍정정서를 경험 할 수 있도록 해야 하며, 경기 중 이를 유지할 수 있도록 하는 전략이 요구된다. 이러한 관계는 훈련에 대한 관여 도를 강화시켜 결국 경기력 향상을 도모할 수 있는 정보 를 제공한다고 이해할 수 있다. 이러한 결과는 시합에 출 전하는 선수들이 경험하는 정서에 따라 조절초점이 변화 하고 이러한 조절초점의 변화는 훈련행동을 변화시킬 수 있다는 근거를 제공하였다. 따라서 정서의 특성 상 선수 가 느끼는 정서를 조절할 수는 없지만 느끼는 정서에 대 한 인식을 유도하고, 이러한 정서가 향상초점으로 전환시 킬 수 있는 긍정적 목표설정과 훈련행동의 교정 및 인지 적 변화를 이끌어내야 한다. 그러므로 훈련에 대한 중요 성과 조절 및 성공적인 결과를 예측할 수 있는 관여도의 증진을 위한 전략구축을 할 수 있을 것이다.

또한 본 연구의 결과는 기존의 정서 및 조절초점 간의 관계를 밝혀온 연구를 지지하고 있으며, 조절초점과 관여 의 관계도 규명되었다는 것에 의미를 찾을 수 있다.

\section{결 론}

본 연구는 엘리트 사격 선수들이 시합에 대한 정서와 조절초점 및 훈련관여의 관계를 탐색하고, 이를 조절 할 수 있는 전략을 구축하기 위한 정보 제공의 목적이 있다.

이에 228 명의 엘리트 사격 선수들을 표집하여, 설문을 실시하였으며, 연구절차와 자료 분석에 근거하여 다음과 같은 연구 결론을 도출하였다.

첫째, 엘리트 사격 선수들이 시합 시 경험하는 정서 요 인은 불안, 놀람, 혐오, 분노, 즐거움, 죄책감, 흥미의 7 가 지로 나타났으며, 사격 선수들이 경험하는 동기는 향상초 점과 예방초점의 2 가지로 나타났다. 또한 훈련 관여는 선 행연구와 동일하게 인지적, 구도적, 정서적, 행동적 훈련 관여 요인으로 나타났다.

둘째, 변수들의 기초 통계치를 산출한 결과, 시합에 대 해 선수들이 경험하는 정서는 즐거움, 흥미, 놀람, 불안, 분노, 죄책감, 혐오 정서의 순서로 나타났으며, 조절초점 의 경우 향상 초점 성향이 높은 것으로 나타났다. 또한 선 수들은 훈련관여 중 인지적 관여와 정서적 관여가 높은
것으로 나타났다.

셋째, 차별적 정서와 조절초점 간의 상관관계를 분석 한 결과 놀람, 즐거움, 흥미 정서는 향상초점과 정적 관계 를 보였으며, 분노, 죄책감은 예방초점과 정적 관계가 있 었다. 또한, 불안, 혐오 정서는 향상초점과는 부적 관계 를, 예방초점과는 정적 관계가 있는 것으로 나타났다. 마 지막으로 관여도는 불안이나 혐오 정서와는 부적관계를 나타냈으며, 즐거움이나 놀람 정서와는 정적 관계를 나타 내었다. 조절초점과 관여도의 관계는 향성초점이 4 개의 관여도와 정적관계가 있는 것으로 나타났으며, 예방초점 은 관계가 없는 것으로 나타났다.

넷째, 차별적 정서와 조절초점 간의 다중회귀분석을 한 결과 즐거움, 혐오, 흥미 정서가 향상초점에 영향을 주 고 있었으며 이 중 즐거움 정서가 가장 유의미한 영향을 주고 있었다. 반면 예방초점은 불안, 죄책감, 분노, 흥미 의 정서가 유의미하게 나타났으며 이 중 불안정서가 예방 초점에 가장 많은 영향을 미치는 요인으로 나타났다. 향 상초점은 인지적, 정서적, 주도적, 행동적 관여에 긍정적 영향을 미치는 것으로 나타났으나, 예방초점은 인지적 관 여에 부정적 영향을 미치는 것으로 나타났다.

마지막으로 긍정적 정서인 즐거움과 흥미 정서는 향상 초점을 강화시켜 훈련관여에 긍정적 영향을 미치는 것으 로 나타났으나, 예방초점과는 유의한 경로가 나타나지 않 았다. 불안과 분노 정서는 예방초점을 증가시키는 것으로 나타났으며, 예방 초점은 다른 관여도에 무의미한 영향을 미쳤으며, 특히 인지적 관여를 감소시키는 것으로 나타났 다. 이러한 결과로 볼 때 선수들은 보다 긍정적인 정서를 경험할수록 시합에 대한 향상초점이 향상되어, 훈련에 대 한 관여도를 증가시키지만, 부정적인 정서의 경험은 시합 에 대한 예방초점을 자극하여 훈련에 대한 관여 행동을 저해시키거나 영향을 미치지 않음을 알 수 있었다.

이러한 결과를 토대로 후속 연구에서 수행해야할 네용 을 제언하면 다음과 같다. 먼저 시합에 대한 정서 인식은 개인의 심리적 상태나 경기력 수준 및 대처 방법에 따라 다르게 나타날 수 있다. 그러므로 연구 참여자들의 성별 이나 우수여부 등 배경 특성에 따른 연구변수들의 차이를 살펴 볼 필요가 있으며, 훈련관여를 증진시켜 성공적인 시합을 이끌어 낼 수 있는 다양한 전략을 제시하는 연구 가 수행될 필요가 있다. 


\section{참고문헌}

Adie, J. W., Duda, J. L., \& Ntoumanis, N. (2010). Achievement goals, competition appraisals, and well- and ill-being of elite youth soccer players over two competitive seasons. Journal of Sport and Exercise Psychology, 32, 555-579.

Adie, J.W., Duda, J.L., \& Ntoumanis, N.(2008). Achievement goals, competition appraisal, and the psychological and emotional welfare of sport participants. Journal of Sport and Exercise Psychology, 30, 302-322.

Brenninkmeijer, V., \& Hekkert-Koning, M. (2015). To craft or not to craft: The relationships between regulatory focus, job crafting and work outcomes. Career Development International, 20(2), 147-162.

Buss, D. M. (2000). The evolution of happiness. American Psychologist, 55, 15-23.

Byun, S, Y \& Jo, H, I, (2011). The Effect of Emotional Experience, Emotional Expressiveness, and Use Motivation on Addiction to Internet and Cellular phone. Journal of Human Understanding and Counseling, 32(1).119-133.

Choi, H, Y, \& Lee, J, Y, Jang. J, H,(2011). The Effect of Emotional Intensity and Emotional Awareness Clarity on the Binge Eating Behavior of High School Girls -Mediating Effect of Avoidant Emotion Regulation Style-. Korea Journal of Counseling. 12(5). 1579-1597.

Cole, P. M., Michel, M. K., \& Teti, L. O. (1994). The development of emotion regulation and development of emotion regulation and dysregulation: A clinical perspective. In N. A. Fox (Ed.), The development of emotion regulation. Biological and behavioral consideration (pp.73-100).

Dugdale, J. R., Eklund, R. C., \& Gordon, S. (2002). Expected and unexpected stress in major international competition: Appraisal, coping, and performance. The Sport Psychologist, 16, 20-33

Ekkekakis, P., Hartman, M.E., \& Ladwig, M.A. (2020). Affective responses to exercise. In G. Tenenbaum \& R.C. Eklund (Eds.), Handbook of sport psychology (4th ed., pp. 233-253). New York: Wiley.

Ekman, P., \& Friesen, W. V. (1975). Unmasking the face. Englewood Cliffs, NJ: Prentice Hall.

Fredricks, J A., Blumenfeld, P. C., \& Paris A. H. (2004). School Engagement : Potential of the concept, stare of the evidence. Review of Educational Reseurcb, 74, 59-109

Gondola, J. C., \& Tuckman, B. W. (1982). Psychological mood state in average marathon runners. Perceptual and Skills, 55, 1295-1300.

Greenberg, L. S. (2001). Emotion-focused therapy. Coaching clients to work though their feelings. Washington: American Psychological Association.

Gustafsson, H., \& Skoog, T. (2012). The mediational role of perceived stress in the relation between optimism and burnout in competitive athletes. Anxiety Stress Coping. 2012 Mar; 25(2):183-99.

Hamstra, M. R., Bolderdijk, J. W., \& Veldstra, J. L. (2011). Everyday risk taking as a function of regulatory focus. Journal of research in personality, 45(1), 134-137.

Han, J, W,(1997). The influences of emotional expressivity on physical health and subjective well-being, Graduate School. Seoul University.

Hanin, Y. L. (2004). Emotion in Sport: the Individual Zones of Optimal Functioning (IZOF) model. In C. D. Spielberger(Ed.). Encyclopedia of Applied Psychology. 1, 739-750.

Higgins, E. T. (1997). Beyond pleasure and pain. American Psychology, 52(12), 1280 - 1300.

Higgins, E. Tory. (1987). Self \& Discrepancy: A Theory Relating Self and Affect. Psychological Review, 94(3), 319-340.

Hong, J, H,(2005). The Development of self-regulatory focus seale in sport. Journal of sport science research, 23, 137-151.

Hue, J, H, \& Oh, C, K,(2014). The effect of negative emotions and EA on adolescents` SWB. Korea Journal of Counseling. 15(6). 2401-2415

Hwang, O, C, \& Park, J, G,(2014). The Relationships between Athletes Goal Orientations and Emotions: The Moderating Effects of Perceived Control and Cognitive Appraisals . Korean Society of Sport Psychology, 25(1), 51-65.

Izard, C. E. (1971). The face of emotion. New York: Appleton-Century-Crofts.

Izard, C. E. (1977). Human emotions. New York: Plenum Press. Izard, Carroll E. , Libero, Deborah Z., Putnam, Priscilla, Haynes,O. Maurice. (1993). Stability of emotion experiences and their relations to traits of personality. Psycscan Developmental psychology : 59

Jones, M., Meijen, C., McCarthy, P. J., \& Sheffield, D. (2009). A theory of challenge and threat states in athletes. 
International Review of Sport and Exercise Psychology, 2(2), 161-180.

Kalat, J. W., \& Shiota, M. N. (2007). Emotion. Wadworth: Cengage Learning.

Kim, H, J \& Kim, C, K,(2007). The Appearance Interest and Related Factors of College Women Students Major in Beauty Art . Jounal of The Korean Society of cosmetology, 13(1). 106-113.

Kim, J, Y, \& Lee, Y, S,(2014). The difference of Optimism, Fear of negative evaluation and Emotional maladaptation behaviors by clusters based on emotional experience: Emotional awareness clarity and Ambivalence over emotional expression. Korea Journal of Counseling, 15(1). 145-159.

Kim, S, H(2010). The effects of parents, teacher's social supports and emotion regulation perceived by examinee on test anxiety. Graduate School of Education, Sung Kyun kwan University.

Kim, S, H(2012). Effects of Student Involvement in Lesson on Academic Achievement and Satisfaction Focusing on the Self-Regulatory Focus. Graduate School of Education, Gongju National University.

Kim, Y, D(2011). Do All Financial Consumers Have the Same Emotional Responses and Satisfaction Level in Gain or Loss Domain? -Differences of Intensity of Emotional Type and Satisfaction in Terms of Regulatory Focus . Journal of consumer studies, 22(3), 25-55.

Lazarus(1991). Emotional and adapatation. New York/Oxford: Oxford University Press.

Lazarus, R. S. (2000). How emotions influence performance in competitive sports. The Sport Psychologist, 14, 229 - 252.

Lee, B, R, \& Jung, G, H,(2017). The Test of Hierarchical Model and Validity of The Korean Version of Sport Motivation Scale(SMS-K). Korean Journal of Sport Science. 28(1). 1-13.

Lee, C, S,(2014). The Mediating Effects of Emotions in the Relationship between Cognitive Appraisals and Performance Strategies among Adolescent Boxers. Korean Society of Sport Psychology. 25(1). 77-88.

Lee, G, Y, \& Jang, H, S,(2013). Effects of Conscientiousness and Perfectionism on Academic Engagement: Mediation Effects of Self-regulation. The Korean Journal of Social and Personality Psychology. 27(2), 127-142.

Lee, J. Y., Jang, H. S. (2013). Effects of Conscientiousness and Perfectionism on Academic Engagement: Mediation Effects of Self-regulation. Korean Journal of Social and
Personality Psychology. 27(2), 127-142.

Lee, S, H, \& Kim, B, M, Yoo, S, E,(2012). 차Validation of the Differential Emotions Scale-IV(DES-IV) in a Korean population. Korean Journal of Psychology: General. 31(1). 147-167.

Lee. C, R \& Jung, N, W,(2012). The Relationship of Affect Intensity and Emotion Dysregulation: The Mediating Effect of Experiential Avoidance. Journal of Human Understanding and Counseling. 33(1).139-158.

McCarthy, P. J. (2011). Positive emotion in sport performance: Current status and future directions. International Review of Sport and Exercise Psychology, 4(1), 50- 69.

Moon, B, R \& Lee, R, J, Kim, D, H,(2009). Verification of Validation of Sport Emotion Scale and Relationship of Sport Motivation. Korean Society of Sport Psychology, 20(2). 31-46.

Nicholls, A. R., Polman, R. C. J., \& Levy, A. R. (2012). A path analysis of stress appraisals, emotions, coping, and performance. Psychology of Sport and Exercise, 13, 263-270

Park, J, G, \& Y, J,(2013). Cognitive Appraisal and Performance Satisfaction among Athletes: The Mediating Effects of Emotion Regulation and Emotion. Korean Society of Sport Psychology, 24(2). 127-145.

Park, J, K \& Choi, M, S,(2003). Emotion management of sports players. Journal of coaching development, 5(2). 117-133.

Park, S, H,(2012). The examination of time-series stability on self-determination motivation theory for sport performance anticipation: latent growth modeling application. Graduate School, Korea University

Park, S. H. (2012). The examination of time-series stability on self-determination motivation theory for sport performance anticipation: Latent growth modeling application. Korean ournal of Physical Education, 51(2), 157 - 167.

Pham, Michel, and Hannah H. Chang (2010), Regulatory Focus, Regulatory Fit, and the Search and Consideration of Choice Alternatives, Journal of Consumer Research, 37(4), 626-640.

Pintrich, P. R. (2004). A conceptual framework for assessing motivation and self-regulated learning in colleage students. Educational Psychology Review, 16(4), 385-409.

Pondman, A. (2015). The usefulness of job crafting: Astudy on the relationships between regulatory focus, job crafting, career competencies and positive work outcomes (Master's thesis). 
Prapavessis, H. (2000). The POMS and sports performance: A review. Journal of Applied Sport Psychology, 12, 34-48.

Ralf Brand, Panteleimon Ekkekakis(2017). AffectiveReflective Theory of physical inactivity and exercise. German Journal of Exercise and Sport Research. 48(1). 48-58.

Ruthig, J. C., Perry, R. P., Hladkyj, S., Hall, N. C., Pekrun, R., \& Chipperfield, J. G. (2008). Perceived control and emotions: Interactive effects on performance in achievement settings. Social and Psychological Education, 11, 161-180.

Ryan, R. M., \& Deci., E. L. (2000). Intrinsic and extrinsic motivation: Classic definitions and new directions. Comtemporary Educational Psychology, 25, 54-67.

Salovey, P., \& Mayer, J. D. (1990). Emotional intelligence. Imagination, Cognition and Personality, 9, 185-211.

Seong, C, H, \& Jang, C, W, Moon, K, W, \& Choi, M, $\mathrm{R},(2015)$. Validation of Athlete's Training Engagement Scale. Korean Society of Sport Psychology, 26(3). 41-53.

Seong, C, H, \& Jang, C, W,(2020). Structural Relationship among Conscientiousness and Perfectionism, Self-regulated Motivation and Training Engagement in Sport. Korean Journal of Sport Science, 31(1). 13-25

Seong, C, H, \& Park, S, H,(2016). The Effect of Regulatory Focus on Motivation Level among Ssireum player. Korean Journal of Sport Science, 27(3). 656-665.

Shaver, P., Schwartz, J., Kirson, D., \& O'Connor, C. (1987). Emotion knowledge: Further exploration of a prototype approach. Journal of Personality and Social Psychology, 52, 1061-1086

Skinner, E. A., Wellborn, J. G., \& Connell, J. P. (1990). What it takes to do well in school and whether Ive got it: A process model of perceived control and children's engagement and achievement in school. Journal of Educational Psychology, 82(1), 22-32.
Skinner. E. A., \& Belmont, M, J. (1993). Motivation in the classroom; Reciprocal effect of teacher behavior and student engagement across the school year. Journal of Educational Psychology, 85, 571-581

Sloan, D. M. (2004). Emotion regulation in action: Emotional reactivity in experiential avoidance. Behaviour Research and Therapy, 42, 1257-1270.

Uphill, M. A., \& Jones, M. V. (2012). Antecedents of emotions in elite athletes: A cognitive motivational relational theory perspective. Research Quarterly for Exercise and Sport, 78(1), 79-89.

Vallerand, R. J. (2004). Intrinsic and Extrinsic Motivation in Sport. Encyclopedia of Applied Psychology, 2, 427-435.

Yoo, J,(2012). Cognitive-Motivational-Relational Theory of Emotion: Sport Research and Emotional Regulation. Korean Journal of Sport Science, 23(4), 1-19.

Yoon. B, S \& Jung, B, K,(2009). Relationship between BIS/BAS and Interpersonal Relationship on Mediating Emotional Awareness, Suppression, and Expression. Korea Journal of Counseling, 10(1). 219-233

You, J. W., Song, Y. H. (2013). Probing the Interaction Effects of Task Value and Academic Self-efficacy on Learning Engagement and Persistence in an e-Learning Course. Journal of Learner-Centered Curriculum and Instruction, 13(3), 91-112.

Yun, J, H,(2016). Validation of model analysis according to the severity of crowding of digital models obtained by intraoral and model scanners. Doctoral dissertation, Graduate School, Yonsei University.

김경희(1995). 정서란 무엇인가?. 서울: 민음사

김인자 역 (1994). 적응심리. 서울: 민음사

정청희, 김병준 $(2000)$. 스포츠 심리학의 이해. 서울: 금광출 판사

조은경 (1995). 정서적 균형과 삶의 질. 한국심리학회 학술대 회 자료집, 1995(1), 23-43. 


\title{
엘리트 사격 선수들이 시합 시 지각하는 시합정서와 조절초점 및 훈련관여의 관계
}

\author{
박상혁 ${ }^{1}$, 성창훈 ${ }^{2}$, 박인혜 ${ }^{3}$ \\ ${ }^{1}$ 한국스포츠정책과학원 선임연구위원 \\ ${ }^{2}$ 인천대학교 교수 \\ 3광운대학교 초빙교수
}

〔목적〕 본 연구는 엘리트 사격 선수들이 지각하는 시합 시 정서와 조절초점 및 훈련관여의 관계를 알아보는 목적으로 수행되었다. 〔방법) 이에 228명의 엘리트 사격 선수들을 표집하고, 차별적 정서와 조절초점 및 훈련 관여 척도를 활용하여 자료분석에 근거한 연구결과를 도출하였다. (결과) 정서와 조절초점 및 훈련관여의 상 관관계를 분석한 결과 놀람, 즐거움, 흥미의 긍정정서는 향상초점과 정적 관계를 보였으며, 분노, 죄책감은 예방초점과 정적 관계가 있었다. 훈련관여 요인은 부정적 정서와는 부적관계를 보였으며, 긍정적 정서와 향상 초점과는 정적 상관을 나타내었다. 차별적 정서와 조절초점 간의 다중회귀분석을 한 결과 즐거움, 혐오, 흥미 정서가 향상초점에 영향을 주고 있었으며 이 중 즐거움 정서가 가장 유의미한 영향을 주고 있었다. 반면 예방 초점은 불안, 죄책감, 분노, 흥미의 정서가 유의미하게 나타났으며 이 중 불안정서가 예방초점에 가장 많은 영향을 미치는 요인으로 나타났다. 훈련관여에는 전반적으로 향상초점이 영향을 미치는 것으로 나타났다. 마 지막으로 긍정적 정서는 향상초점과 훈련관여에 긍정적 영향을 미쳤으며, 부정적 정서는 예방초점에 영향을 미치고 인지적 관여를 감소시키는 것으로 나타났다. 〔결론) 시합에 대한 긍정적 정서는 향상초점을 강화시켜 훈련관여를 증진시키는 과정이 확인되었지만, 부정적 정서는 예방초점을 강화시켜 인지적 관여를 감소키는 것 으로 나타났다.

주요어: 향상초점, 예방초점, 흥미, 놀람, 정서 